
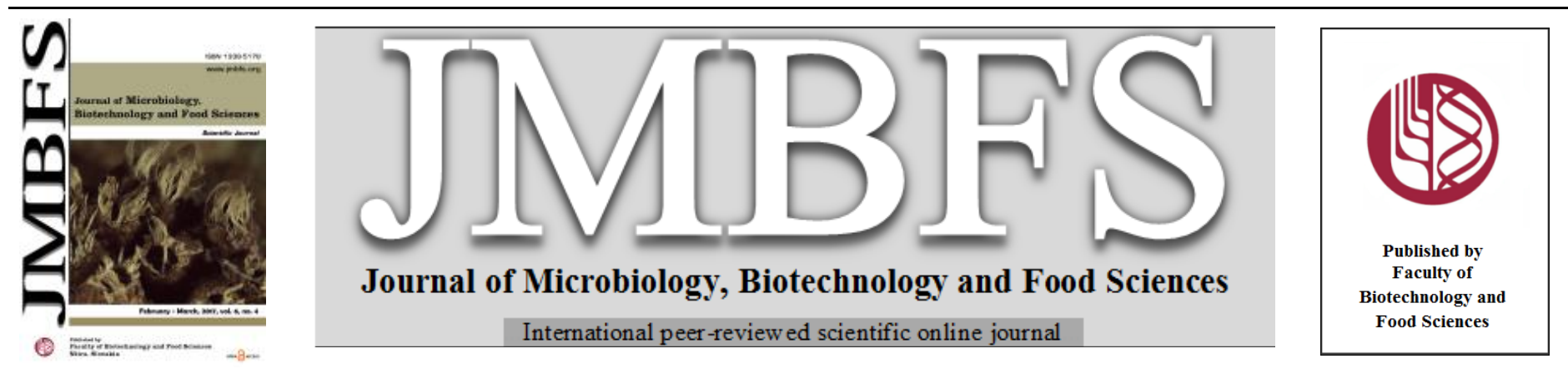

\title{
GENETIC VARIATION OF MAIZE GENOTYPES (ZEA MAYS L.) DETECTED USING SDS-PAGE
}

\section{Martin Vivodik*, Želmíra Balážová, Zdenka Gálová, Lenka Petrovičová}

Address(es):

Slovak University of Agriculture in Nitra, Faculty of Biotechnology and Food Sciences, Department of Biochemistry and Biotechnology, Tr. A. Hlinku 2, 949 76, Nitra, Slovak Republic.

*Corresponding author: vivodik.martin@gmail.com

doi: $10.15414 / j m b f s .2017 .6 .4 .1086-1089$

\section{ARTICLE INFO}

Received 1. 12. 2016

Revised 14. 12. 2016

Accepted 18. 12. 2016

Published 1. 2. 2017

Regular article OPEN $\partial_{\text {ACCESS }}$

\begin{abstract}
The assessment of genetic diversity among the members of a species is of vital importance for successful breeding and adaptability. In the present study 20 old genotypes of maize from Hungary, Union of Soviet Socialist Republics, Poland, Czechoslovakia and Slovak Republic were evaluated for the total seed storage proteins using sodium dodecyl sulphate polyacrylamide gel electrophoresis (SDSPAGE) through vertical slab unit. The number of total scorable protein bands was twentythree as a result of SDS-PAGE technique but those that were not cosistent in reproducibility and showed occasional variation in sharpness and density were not considered. Out of twentythree polypeptide bands, 6 (31\%) were commonly present in all accessions and considered as monomorphic, while 17 (65\%) showed variations and considered as polymorphic. On the basis of banding profiles of proteins of different $\mathrm{kDa}$, gel was divided into zones A, B and C. The major protein bands were lied in zones A and B, while minor bands were present in zones C. In zone A out of 10 protein bands, 1 were monomorphic and 9 were polymorphic. In zone B out of 8 protein bands, 3 was monomorphic and 5 was polymorphic and in zone $\mathrm{C}$ out of 5 protein bands, 2 were monomorphic whereas 3 polymorphic. The dendrogram tree demonstrated the relationship among the forty registered old maize genotypes according to the similarity index, using UPGMA cluster analysis. The dendrogram was divided into three main clusters. The first cluster contained Czechoslovakia genotype Mikulická and the second cluster contained Czechoslovakia genotypes Celchovicka ADQ. Cluster 3 was divided into 3 subclasters. Similarly the present study of genetic variability in the seed storage polypeptide determined by SDS-PAGE technique proved that it is fruitful to identify genetic diversity among accessions of maize.
\end{abstract}

Keywords: maize; dendrogram; SDS-PAGE; genetic diversity

\section{INTRODUCTION}

Maize (Zea mays L.) is an annual, cross-pollinated by wind and the only monoecious among cereal crops to have male and female inflorescences on separate branches of the same plant. It belongs to grass family Poaceae (Gramineae) which is leading in importance in the order Poales (Bremer $\boldsymbol{e t}$ al. 2003). This family contributes to the world economy, food and industry through valuable crops i.e. wheat, rice and maize (Mabberley, 2008). Being most domesticated with controversy in origin and evolution, there is one school of thoughts that maize is the nearest descendant of Mexican teosinte (Dowswell $\boldsymbol{e t}$ al., 1996). There is no doubt that human beings directly or indirectly depend on plants for various purposes for which they domesticated these with the passage of time and flourished with spreading communities, undergone through evolution, passing through various cultivating methodologies throughout the world (Larik, 1994).

Maize seed consists of two types of protein i.e., zein and non-zein protein. The term zein is used for prolamins in maize which is alcohol soluble protein and could be extracted with ethanol (Lawton, 2006). Zein is major seed storage protein of maize (Freitas et al., 2005) and consists of one major and three minor classes and these four classes constitute approximately $50-70 \%$ of maize endosperm (Vasal, 1999). The non-zein protein consists of globulins (3\%), glutelins $(34 \%)$ and albumins $(3 \%)$. Zein is specific to maize endosperm (Prasanna et al., 2001) and not present in any other part of plant.

Proteins are primary gene products of active structural genes; their size and amino acids sequence are the direct results of nucleotide sequences of the genes; hence, any observed variation in protein systems induced by any mutagen is considered a mirror for genetic variations (Hamoud et al., 2005). Variation in theDNAcoding sequences frequently causes variation in the primary conformation of the proteins. Determination of protein molecular weight (MW) via polyacrylamide gel electrophoresis (PAGE) in the presence of sodium dodecyl sulfate (SDS) is a universally used method in biomedical research; (Ranjan et al., 2013) concluded that electrophoresis (SDS-PAGE) of proteins can be economically used to assess genetic variation and relation in germplasm and also to differentiate mutants from their parent genotypes. Some studies used SDS-PAGE for detection of alterations in protein profiles occurring during exposure to electric field (Hanafy et al., 2006; Dymek et al., 2012). So far, several investigations on the discrimination between crop genotypes using SDSPAGE have been carried out by Yoon et al., (2010); Osman et al., (2013); Chňapek et al., 2014; Iqbal et al., (2014); Iqbal et al., (2014); Khan et al., (2014); Petrovičová et al., 2014; AL-Huqail et al., (2015); Chňapek et al., 2015; Gregova et al., (2015); Kačmárová et al., (2016); Kut'ka Hlozáková et al., 2015; Tomka et al., (2015); Socha et al., (2016).

The objectives were to find out the level of genetic variability present in 20 maize germplasm by using the electrophoretic profiles of total seed proteins with different molecular weights through SDS- PAGE.

\section{MATERIAL AND METHODS}

Maize genotypes (20) were obtained from the Gene Bank VURV Praha-Ruzine (Czech Republic) and from the Gene Bank in Pieštany, the Slovak Republic (Table 1).

SDS-PAGE was carried out according to the standard reference ISTA method (Wrighley, 1992). Storage proteins were extracted from individually ground seeds using extracting using a buffer composed of $6.25 \mathrm{~mL}$ Tris $(1.0 \mathrm{~mol} \mathrm{~L}-1, \mathrm{pH}$ =6.8), $10 \mathrm{~mL}$ glycerol, $12.05 \mathrm{~mL} \mathrm{H}_{2} \mathrm{O}$ and $2.0 \mathrm{~g} \mathrm{SDS}$, diluted with mercaptoethanol and $\mathrm{H}_{2} \mathrm{O}$ in a 17:3:40 (v/v) proportion. The buffer was added to flour in a 1:25 (w/v) proportion. Extraction was performed at room temperature overnight and heating in boiled water for 5 minutes, centrifugation at $5000 \mathrm{xg}$ for $5 \mathrm{~min} .10 \mu \mathrm{l}$ of extracts were applied to the sample wells. The gel $(1.0 \mathrm{~mm}$ thick $)$ consists of two parts: stacking gel (3.5\% acrylamide, $\mathrm{pH}=6.8$ acrylamide) and resolution gel $(10 \%$ acrylamide, $\mathrm{pH}=6.8)$. Staining of gels was performed in a solution of Coomassie Brilliant Blue R250 dissolved in acetic acid and methanol solution. Gel was scanned with densitometer GS 800 (Bio-Rad) and evaluated with Quantity One-1D Analysis Software. 
$\underline{\text { Table } 1 \text { List of } 20 \text { analyzed genotypes of maize }}$

\begin{tabular}{|c|c|c|c|}
\hline & Genotypes & Country of origin & $\begin{array}{c}\text { Year of } \\
\text { registration }\end{array}$ \\
\hline 1. & Moldavskaja & $\begin{array}{c}\text { Union of Soviet Socialist } \\
\text { Republics }\end{array}$ & 1964 \\
\hline 2. & $\begin{array}{l}\text { Bučiansky Konský } \\
\text { Zub }\end{array}$ & Slovak Republic & 1964 \\
\hline 3. & $\begin{array}{l}\text { Hodoninský konský } \\
\text { zub žltý }\end{array}$ & Czechoslovakia & 1964 \\
\hline 4. & M Silokukurica & Hungary & 1964 \\
\hline 5. & Valticka & Czechoslovakia & 1964 \\
\hline 6. & Przebedowska Biala & Poland & 1964 \\
\hline 7. & Toschevska & Slovak Republic & 1964 \\
\hline 8. & $\begin{array}{l}\text { Šamorinsky konský } \\
\text { zub }\end{array}$ & Hungary & 1964 \\
\hline 9. & Wielkopolanka & Poland & 1964 \\
\hline 10. & Czechnicka & Poland & 1964 \\
\hline 11. & Manalta & Czechoslovakia & 1964 \\
\hline 12. & Zlota gorecka & Poland & 1964 \\
\hline 13. & Celchovicka ADQ & Czechoslovakia & 1964 \\
\hline 14. & Belaja mestnaja & $\begin{array}{c}\text { Union of Soviet Socialist } \\
\text { Republics }\end{array}$ & 1964 \\
\hline 15. & Bučanská žltá & Slovak Republic & 1964 \\
\hline 16. & Iregszemeseil 2 hetes & Hungary & 1964 \\
\hline 17. & Dnepropetrovskaja & $\begin{array}{c}\text { Union of Soviet Socialist } \\
\text { Republics }\end{array}$ & 1964 \\
\hline 18. & Bezuncukskaja & $\begin{array}{c}\text { Union of Soviet Socialist } \\
\text { Republics }\end{array}$ & 1964 \\
\hline 19. & Mikulická & Czechoslovakia & 1964 \\
\hline 20. & $\begin{array}{l}\text { Aranyozon sarga } \\
\text { lofogu }\end{array}$ & Hungary & 1964 \\
\hline
\end{tabular}

\section{RESULTS AND DISCUSSION}

The number of total scorable protein bands was twentythree as a result of SDSPAGE technique but those that were not cosistent in reproducibility and showed occasional variation in sharpness and density were not considered. Based on these bands twenty accessions of maize (Table 1) were screened. Out of twentythree polypeptide bands, $6(31 \%)$ were commonly present in all accessions and considered as monomorphic, while $17(65 \%)$ showed variations and considered as polymorphic. The size of the protein bands obtained through SDS PAGE ranged from 20 to $140 \mathrm{kDa}$. On the basis of banding profiles of proteins of different $\mathrm{kDa}$, gel was divided into zones $\mathrm{A}, \mathrm{B}$ and $\mathrm{C}$ (Figure 1). The major protein bands were lied in zones $\mathrm{A}$ and $\mathrm{B}$, while minor bands were present in zones $\mathrm{C}$. It was noted that different accessions of maize showed more diversity in seed storage proteins in minor bands in comparison to major bands. In zone A out of 10 protein bands, 1 were monomorphic and 9 were polymorphic. In zone B out of 8 protein bands, 3 was monomorphic and 5 was polymorphic and in zone $\mathrm{C}$ out of 5 protein bands, 2 were monomorphic whereas 3 polymorphic. By considering these facts zone $\mathrm{A}$ and $\mathrm{B}$ were more polymorphic.

The dendrogram tree (Figure 2) demonstrated the relationship among the twenty registered old maize genotypes according to the similarity index, using UPGMA cluster analysis. The dendrogram was divided into three main clusters. The first cluster contained Czechoslovakia genotype Mikulická and the second cluster contained Czechoslovakia genotypes Celchovicka ADQ. Cluster 3 was divided into 3 subclasters. In subclaster $3 \mathrm{a}$ was separated genotype Manalta (Czechoslovakia) from other 17 genotypes (Figure 2). Subclaster $3 b$ is divided into subclaster 3 ba and 3 bb. Subclaster 3 ba contained 12 maize genotypes and subclaster 3 bb contained 3 genotypes from Union of Soviet Socialist Republics
(Moldavskaja, Belaja mestnaja and Bezuncukskaja). Subclaster 3c contained one genotypes from Poland - Zlota gorecka and one genotypes from Union of Soviet Socialist Republics - Dnepropetrovskaja. Similarly the present study of genetic variability in the seed storage polypeptide determined by SDS-PAGE technique proved that it is fruitful to identify genetic diversity among accessions of maize.

Similar results were detected by other authors (Yoon $\boldsymbol{e t}$ al., 2010; Osman $\boldsymbol{e t}$ al., 2013; Iqbal et al., 2014; Iqbal et al., 2014; Khan et al., 2014; Merza et al., 2014; AL-Huqail et al., 2015) and these results presented a high level of polymorphism of old maize genotypes detected by SDS-PAGE. Osman $\boldsymbol{e t}$ al., (2013) study genetic relationship between some species of Zea mays using sodium dodecyl sulfate polyacrylamide gel electrophoresis (SDS-PAGE) of seed protein. Autors identified 78 bands across the studied species. The number of bands varies from 17 bands in sample number 5 to 6 in sample number 6 . Iqbal et al., (2014) analyzed 73 genotypes of maize from China, Japan and Pakistan for the total seed storage proteins using sodium dodecyl sulphate polyacrylamide gel electrophoresis (SDS-PAGE). A total of 18 protein bands were recorded. Among these $7(39 \%)$ were monomorphic and $11(61 \%)$ polymorphic, with molecular weight varied from $10 \mathrm{kDa}$ to $122 \mathrm{kDa}$. The aim of Iqbal et al., (2014) was to estimate the genetic diversity across 83 genotypes of maize of Pakistan and Japanese origin using SDS-PAGE. A total of 18 protein subunits were noted out of which 7 (39\%) were monomorphic and $11(61 \%)$ were polymorphic, with molecular weight ranging from 10 to $122 \mathrm{kDa}$. Coefficients of similarity among the accessions ranged between 0.89 and 1.00 . The dendrogram obtained through UPGMA clustering method showed two main clusters: 1 and 2. First cluster contained 9 genotypes, while second cluster contained 74 genotypes. Khan $\boldsymbol{e t}$ al., (2014) study the variation of zein fraction of seed storage protein in maize by sodium dodecyl sulphate polyacrylamide gel electrophoresis (SDS-PAGE) Variation in terms of absence and presence, intensity and molecular size was observed in zein polypeptides. The study of Merza et al., (2014) was conducted to investigate the ability of total soluble seed protein to discriminate among 21 of maize genotypes through using sodium dodecyl sulfate polyacrylamide gel electrophoresis (SDS-PAGE). According to SDS analysis, a total of 118 amplified bands were obtained ranging in their molecular size $18-86 \mathrm{KDa}$. Five out of main nine bands were polymorphic and four monomorphic with an average of polymorphism reaches $55.5 \%$. Phylogenetic tree divided 21 of corn genotypes between two major groups each of them divided in to two subgroups. The first main group included 13 genotypes, while the second main group included eight genotypes. AL-Huqail et al., (2015) used SDS-PAGE to detection of 46 polypeptides bands with different molecular weights ranging from 186.20 to 36.00 KDa. It generated distinctive polymorphism value of $84.62 \%$.

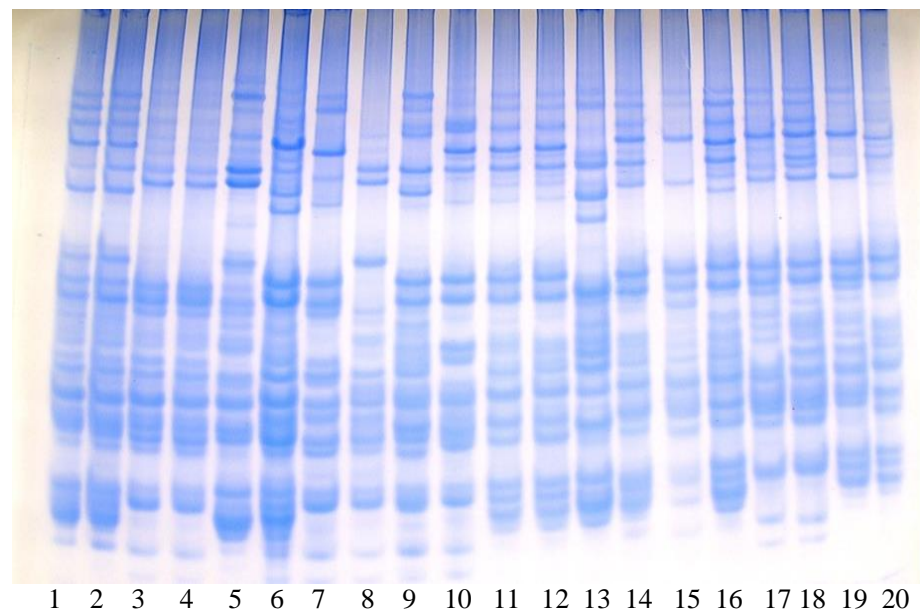

Figure 1 Protein profile showing total seed storage proteins in maize genotypes as a result of SDS-PAGE. Lanes 1- 20 are maize genotypes (Table 1). 


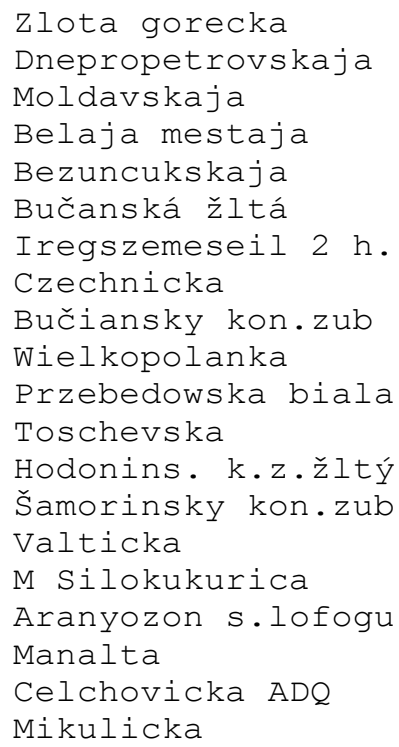

$3 \mathrm{c}$

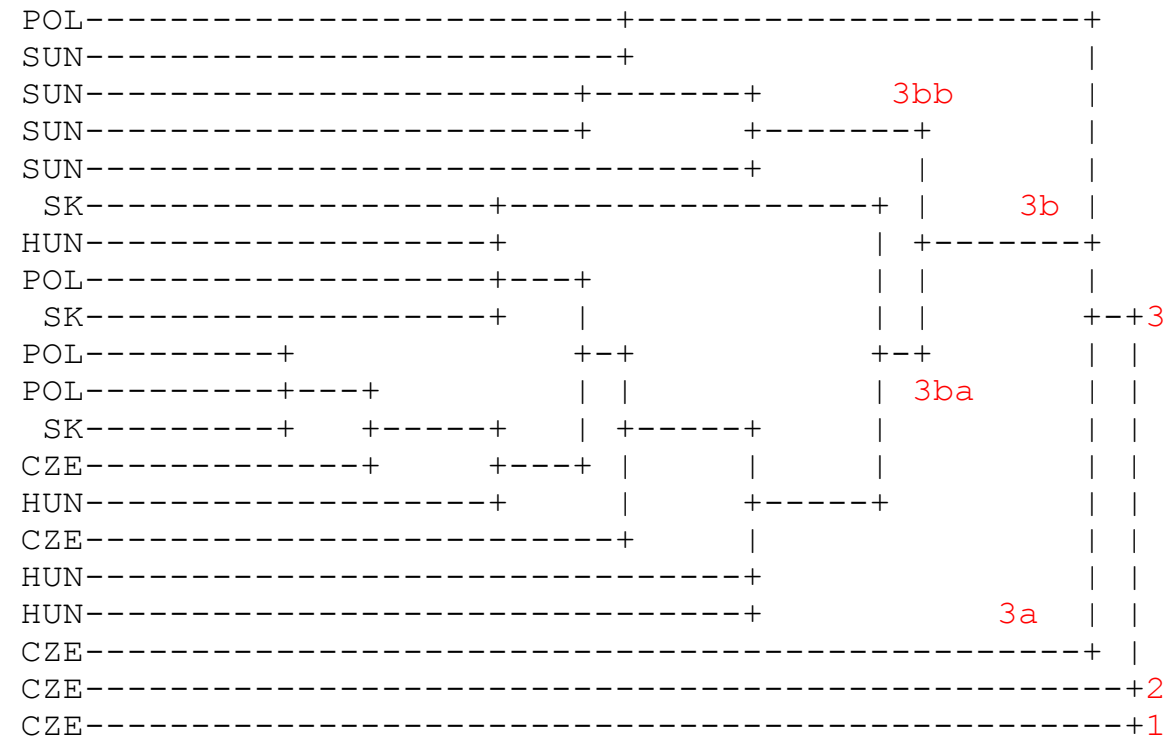

Figure 2 Dendrogram of 20 maize genotypes prepared based on SDS-PAGE markers. CZE - Czechoslovakia, HUN - Hungary, POL Poland, SUN - Union of Soviet Socialist Republics, SK - Slovakia

\section{CONCLUSION}

SDS-PAGE techniques may provide useful information on the level of polymorphism and diversity in old maize genotypes. Twenty maize genotypes originated from the Gene Bank VURV Praha-Ruzine (Czech Republic) and from the Gene Bank in Piestany, the Slovak Republic were very closely related. The dendrogram was divided into three main clusters. The first cluster contained Czechoslovakia genotype Mikulická and the second cluster contained Czechoslovakia genotypes Celchovicka ADQ. Cluster 3 was divided into 3 subclasters. In subclaster 3a was separated genotype Manalta (Czechoslovakia) from other 17 genotypes. Result from this study show that protein markers are powerful and efficient in characterising and identifying of old maize genotypes in addition to their usefulness in phylogenetic studies.

Acknowledgments: This work was co-funded by European Community under project no. 26220220180: Building Research Centre "AgroBioTech" (50\%) and KEGA project No. 021SPU-4/2015 (50\%).

\section{REFERENCES}

AL-Huqail, A. A. and Abdelhaliem, E. (2015). BioMed Research International. vol. 2015, Article ID 874906, 15 pages. http://dx.doi.org/10.1155/2015/874906 Bremer, K., Bremer, B. and Thulin M. (2003). Introduction of Phylogeny and Systematic of Flowering Plants. Symbolae Botanicae Upsalienses, 33(2), 64-73. Dowswell, C. R., Paliwal, R. L. and Cantrell, R. P. (1996). Maize inthe Third World, Westview Press, Inc., Boulder.

Dymek, K., Dejmek, P., Panarese, V. et al., (2012). Effect of pulsedelectric field on the germination of barley seeds. LWT-Food Science and Technology, 47(1), $161-166$.

Freitas, I. R. A., Gananca, F., Santos, T. M., Carvalho, M. A. A., Motto, M. and Vieira, M. C. (2005). Evaluation of maize germplasm based on zein polymorphism from the archipelago of Madeira. Maydica, 50, 105-112.

Gregova, E., Šliková, S., Hozlár, P. (2015). Seed protein electrophoresis for identification of oat registered cultivars. Potravinarstvo, 9(1), 411-416. http://dx.doi.org/10.5219/513

Hamoud, M. A., El-Shanshory, A. R., Al-Sodany, Y. M. and El-Karim, M. S. G. (2005). Genetic diversity among Ipomoea carnea jacq. Populations from different habitats types in Nile-Delta region of Egypt. The Egyptian Journal of Experimental Biology, 1, 1-10.

Hanafy, M. S., Mohamed, H. A. and Abd El-Hady, E. A. (2006). Effect of low frequency electric field on growth characteristics and protein molecular structure of wheat plant. Romanian Journal of Biophysics, 16(4), 253-271.

Chňapek, M., Tomka, M., Balážová, Ž., Gálová, Z. (2014). Protein complex of wheat, buckwheat and maize in relation to celiac disease. J Microbiol Biotech Food Sci, 3(special issue 2), 88-92.

Chňapek, M., Peroutková, R., Vivodík, M., Gálová, Z. (2015). Identification of technologically important genes and their products in the collection of bread wheat genotypes. J Microbiol Biotech Food Sci, 4(special isuue 2), 26-29. http://dx.doi.org/10.15414/jmbfs.2015.4.special2.26-29
Iqbal, J., Shinwari, Z. K., Rabbani, M. A., Khan, S. A. (2014). Genetic variability assessment of maize (Zea mays L.) germplasm based on total seed storage proteins banding pattern using SDS-PAGE. European academic research, 2(2). ISSN 2286-4822

Iqbal, J., Shinwari, Z. K. and Rabbani, M. A. (2014). Investigation of total seed storage proteins of Pakistani and Japanese maize (Zea mays L.) through SDSPAGE markers. Pak. J. Bot., 46(3), 817-822.

Kačmárová, K., Lavová, B., Socha, P., Urminská, D. (2016). Characterization of protein fractions and antioxidant activity of Chia seeds (Salvia Hispanica L.) Potravinarstvo, 10(1), 78-82. http://dx.doi.org/10.5219/563

Khan, A. H., Khan, N., Minhas, N. M., Ghafoor, A. and Rabbani, M. A. (2014) Diversity in seed storage proteins in maize genetic resources: I. variation in alcohol soluble zein protein fraction. Int. J. Agric. Biol., 16, 1015-1018.

Kut'ka Hlozáková, T., Gregová, E., Gálová, Z. (2015). Genetic diversity of Glu-1 in European wheat genetic resources and varieties. J Microbiol Biotech Food Sci, 4(special issue 2), 23-25. http://dx.doi.org/10.15414/jmbfs.2015.4.special2.23$\underline{25}$

Larik, A. S. (1994). Genetic resources and their conservation incrop plants. Plant Breeding by National Book Foundation Isalamabd, Pakistan, 235, 236, 250.

Lawton, J. W. (2006). Isolation of zein using 100\% ethanol. Cer. Chem., 83, $565-568$.

Mabberely, D. J. (2008). Mabberleys Plant-Book: A portable dictionary of plants, their classifications, and uses. 3rd edition. Cambridge Univ. Press.: VIIXVIII, 1-1021.

Merza, T. K., Thamir, A. J., Al-Badeiry, N. A. H. (2014). Genetic discrimination among 21 Corn (Zeay mays L.) varieties through total soluble seed protein profile. Journal of Kerbala University, 12(2), 168-175.

Osman, G., Munshi, A., Altf, F. and Mutawie, H. (2013). Genetic variation and relationships of Zea mays and Sorghum species using RAPD-PCR and SDSPAGE of seed proteins. African Journal of Biotechnology, 12(27), 4269-4276. http://dx.doi.org/10.5897/ajb12.2644

Petrovičová, L., Gálová, Z., Chňapek, M. (2014). Genetic diversity of czechoslovak origin rye varieties (Secale cereale L.) based on protein polymorphism. J Microbiol Biotech Food Sci, 3(special issue 2). 267-269.

Prasanna, B., Vasal, S., Kashun, B. and Singh, N. N. (2001). Quality protein maize. Curr. Sci., 81, 1308-1319.

Rajan, S., Poosapati, A., Vardhan, H. et al., (2013). Seed storage protein profile of few leguminous grains grown in india using SDSPAGE. International Journal of Advanced Biotechnology and Research, 4(4), 505-510.

Socha, P., Tomka, M., Kačmárová, K., Lavová, B., Ivanišová, E., Mickowska, B., Urminská, D. (2016). Comparable efficiency of different extraction protocols for wheat and rye prolamins. Potravinarstvo, 10(1), 139-144. http://dx.doi.org/10.5219/540

Tomka, M., Chňapek, M., Gálová, Z., Urminská, D. (2015). The differences between the old and new barley varieties on the basis of hordein polymorphism with respect to qualitative parameters. J Microbiol Biotech Food Sci, 4(special issue 2), 108-110. http://dx.doi.org/10.15414/jmbfs.2015.4.special2.108-110 
Vasal, S. K. (1999). Quality protein maize story. Proceedings of workshop on improving human nutrition through agriculture: the role of international agricultural research. p: 1-16. IRRI, Los Banos, Philippines

Yoon, J. W., Jung, J. Y., Chung, H. J., Kim, M. R., Kim, Ch. W., Lim, S. T.

(2010). Identification of botanical origin of starches by SDS-PAGE analysis of starch granule-associated proteins. Journal of Cereal Science, 52, 321-326. http://dx.doi.org/10.1016/j.jcs.2010.06.015

Wrigley, C. W. (1992). Identification of cereal varieties by gel elektrophoresis of the grain proteins. Heidelberg: Springer - Verlag, $17-41$. 